\title{
ASSET-BASED RECOGNITION CRITERIA: A COMPREHENSIVE VIEW
}

\section{Introduction}

With the increasing importance of internally created assets and their implications for the financial position of a business entity and with coincide of revisiting the conceptual framework (CF) for financial reporting and one of these projects is the asset definition and recognition phases (at the time of writing this paper). This paper aims to present a comprehensive view of the assets recognition criteria by providing a coherent set of pre-measurement themes that should be taken into consideration to be a candidate asset. This review has resulted in seven themes as follows: first, the social constructionist nature of the conceptual framework; second, the nature of assets; third, the changing nature of asset recognition; fourth, asset measurement bases; fifth, entity specific vs market specific recognition; sixth, the economic resource comprising 'rights'; seventh, the role of 'separability' in asset recognition.

Recognition of intangible assets has been given much attention in recent years with the evolution of internally created assets. This increasing importance of asset recognition has led to considerable debate within accounting communities over the issue of accounting for unrecognisable assets for financial reporting issues. It has remained a problematic topic as evidenced by a considerable volume of literature (Munter and Ratcliffe, 1980; Schuetze, 2001; Egginton, 1990; Napier and Power, 1992; Tollington, 1998; Booth, 2003; Walker, 2003; Walker and Jones, 2003; Erhard, 2004; Johnson, 2004; Bullen and Cook, 2005; Gore and Zimmerman, 2007; Miller and Bahnson, 2007; Brouwer et al., 2015). It was not until 2006 that the IASB announced a new project to revisit the Conceptual Framework for financial reporting with a view to completing, updating, refining and converging into a common improved CF (Bullen and Cook, 2005). This paper presents a comprehensive view of asset recognition criteria by providing a coherent set of pre-measurement themes that should be taken into consideration to be a candidate asset. The objective of financial reporting is to provide users of 
financial statements with relevant information that is useful for credit and investment decisions. According to the IASB CF (2001), the objective of the CF for financial reporting is to provide information about the financial position, performance and changes in financial position of an enterprise that is useful to a wide range of users in making economic decisions (CF12-14). As a result, any physical or non-physical value that is likely to affect an entity’s current financial position or its future performance should be reported in its annual accounts. There are three existing aspects for the asset recognition process: first, should an asset be identified to be recognised in the financial statements (meets the asset definition)? Second, should an asset meet the recognition criteria for the inclusion in the financial statements? And finally, the use of a particular valuation method to measure the asset in question. In 2006, the IASB/FASB issued the first working definition of an asset with a view to overcoming the shortfalls in the existing definition. This paper addresses the aspects in two phases for the asset recognition process: the pre-measurement phase and the measurement phase. The former deals with the asset definition and the asset recognition criteria while the latter deals the valuation and choice of a particular measurement basis for measuring the asset. The absence of a consensus on the proper accounting for the pre-measurement phase for asset recognition has been the motive for this research. The research aim is to provide a comprehensive view of the asset-based recognition criteria for the pre-measurement themes.

The paper demonstrates the need for a coherent set of recognition criteria for the premeasurement phase of an asset recognition process. The comprehensive review of this asset based recognition criteria presented in this paper breaks free from the narrow definitional and rule based perspective of accounting epistemology to offer an alternative view based on the recognition of artefacts to recognise the tangible and intangibles assets in the financial statements. This synthesis review added to the body of knowledge by demonstrating the different asset based recognition themes which improves the accounting treatment for asset recognition process. In addition, this research has directed the attention of standard setters to the missing parts in the CF for financial reporting and why the currently un-recognisable assets 
are not recognised in the financial statements. In addition to, the timing of conducting this research is a distinct contribution when the conceptual framework for financial reporting is under review.

This synthesis review is divided into eight sections as follows: first, the social constructionist nature of the conceptual framework; second, the nature of assets; third, the changing nature of asset recognition; fourth, asset measurement bases; fifth, entity specific vs market specific recognition; sixth, the economic resource comprising 'rights'; seventh, the role of 'separability' in asset recognition; eighth, a suggested avenue for asset-based recognition criteria section is discussed. Finally, the conclusion, locating this research in the literature and its contribution to the existing body of literature.

\section{The social constructionist nature of the conceptual framework}

Sprouse (1988, p. 121) argues for accounting to be a 'legitimate’ science, part of that legitimacy being derived from the rules, regulations and procedures of accounting as supposedly grounded on a conceptual framework (CF). Yet, we know, for example, from the inclusion of fair values in many of the recent rules of accounting (IFRS 7, IAS 32 etc.) that this development is detached from the existing CF measurement bases (IASB, 2001, para. 100). In CF paragraph 100, fair value is mentioned under historic cost and not defined or identified as a separate measurement basis - this is instead left to the later IAS 39 rule. In a similar context, Dean and Clarke (2003) argue that the history of the CF is one that is biased towards searching for rational practices for preparing financial statements rather than a unique legal, social, economic and financial framework within which accounting is to function. In both cases, the argument is that accounting practice is largely uninformed by the existence of a CF. Yet, the merits of a CF are still articulated in the literature. Despite the above example, consider the comments of Pyke (1999) who, nevertheless, argues that the main reasons for developing an agreed CF is that it

provides a framework for setting accounting standards, a basis for resolving accounting 
disputes and some fundamental principles which do not have to be repeated in accounting standards; and he is not alone. The need for some kind of CF for financial accounting has been felt in English-speaking countries for many decades (Elling, 1995; Sundgaard, 1997; Sundgaard, 2000; Archer, 1992; Archer, 1993; Gore, 1992; Mozes, 1992). In the USA, this need resulted in the FASB (CF) conceptual framework issued from 1978 to 1985. Internationally, the IASC issued its framework from 1974 to 1989, followed by the IASB's CF in 2001. Yet, some writers (Archer, 1992; Mozes, 1992; Macrve, 1981; Sundgaard, 2000; Loftus, 2003; Newberry, 2003) have stated that it is unlikely that there will be an agreed CF. Page (2005), for example, likened the pursuit of a CF to the hunting of the snark - a mythical creature.

In July 2006, a joint project was agreed between the Financial Accounting Standards Board (FASB) and the International Accounting Standards Board (IASB) for an improved CF for financial reporting, although recently, it has only been assigned to the IASB to complete this project of the revised CF. The four phases of the revised and ongoing CF project are: Phase A: objectives and qualitative characteristics; Phase B: elements and recognition; Phase C: measurement; and finally Phase D: reporting entity. At the time of writing this paper, Phase A was nearly complete. Many of the features presented in Phases A and B are principle based, including the use of definitions. Thus, the epistemology of financial reporting is a defined one, a socially constructed one and one that is, therefore, subject to political policy making decisions that give rise to the numerous debates cited in the previous paragraph (see Barth, 2007).

As will be explored in the following section, the political policy decision-making of the IASB gives priority to a balance sheet centred asset/liability view of accounting. This view is grounded on the Hicksian (1946, pp. 178-9) notion of changes in wealth, plus what is consumed in a period. It follows, to some extent, that the disclosure of income after deducting 
expenses comprehends, first, no distinction between income from operating or holding assets (compare Edwards and Bell, 1961, p. 93; Revsine, 1973, pp. 88-89), whether realised or not (see Bertoni and De Rosa, 2005; Cauwenberge and De Beelde, 2007; IASB, 2003; Newberry, 2003; Barker, 2004 on the notion of 'comprehensive income') and second, the weakening of concepts such as matching (see Lev and Zarowin, 1999; IASB, 2001, para. 95) and realisation too where the disclosure of valuations independently of a transaction effectively pre-empts the point of realisation as a recognition signal. These issues are addressed in the following sections, as well as missing issues such as those, for example, connected with the notion of separability. Additionally, there is a more fundamental starting point to this review that, in a sense, is taken for granted in the above political policy stance and that is the nature of an asset itself. One can make the argument, for example, that one should record comprehensive income, but if one cannot agree on what should be recognised as an asset then the subsequent issue of recording movement in asset values could easily be viewed as a meaningless one to undertake.

\section{The nature of assets: A brief etymology}

Williams (2003) states that the English word 'asset' was adopted from the sixteenth century French word 'asez', which, in turn, was derived from the Latin word meaning 'to sufficiency' (in sufficient quantity). This word was used in the context of an insolvent debtor in settling his/her debts. By the end of the sixteenth century, the meaning of asset had been extended to all property owned by a person or entity which could be made available for his or their debts. Towards the end of the nineteenth century, this view of assets which was understood in commerce, also began to feature prominently in the accounting literature. Alongside this view, there appeared another view of assets; one representing deferred (unallocated) costs (see Williams, 2003). Outlays, which were argued not to relate solely to the current period, were reported in the balance sheet as assets, without regard for whether such outlays represented 
assets in the commonly understood sense of rights of ownership or objects owned that could be exchanged for cash. Subsequently, the notion that assets were unallocated costs was popularised, especially by those who argued that the focus of accounting should be on the profit and loss statement. For example, Paton and Littleton (1940) emphasised the importance of the matching of efforts and accomplishments as measured by costs and revenues (see Littleton, 1953; Engleman, 1954; Williams, 2003). At the same time, the emphasis was on the allocation of revenues and expenses to accounting periods to determine income. Solvency, or debt paying power, was considered of secondary importance.

Williams (2003) states that, towards the second half of the twentieth century, there was a further change to a much broader view of assets as representing 'service potential’ and more recently, 'future economic benefits'. This popular view of assets is reflected in the definitions promulgated by professional accounting bodies in the United States (Financial Accounting Standards Board (FASB), 1980) and the International Accounting Standards Board (IASB) (2001). Unsurprisingly, there is some similarity in the definition of an asset from these two bodies:

\section{Insert Table (1)}

\subsection{Accounting assets as a defined reality}

Definitions occupy a central conceptual role in the accounting domain. Hines (1988) argues, though, that this is because:

If men define things as real, they are real in their consequences. We create a picture of an organisation, or the "economy", whatever you like, and on the basis of that picture (not some underlying real reality of which no-one is aware), people think and act. And by responding to that picture of reality, they make it so: it becomes real in its consequences. And, what is more, when people respond to that picture, and the consequences occur, they see it as proof of our having correctly conveyed reality. Clever isn’t it. That is how society works (Hines, 1988, p. 257, underlining added). 
And if, as Hines implies, there is no 'underlying real reality', then 'a faithful representation of the real-world economic phenomena' (IASB, 2005, 2008) is somewhat problematic. This is because representations of that defined 'picture of reality' are always contestable (Popper, 1962), as is any correspondence to the abstract notion of accounting truth conveyed thereby (see Shapiro, 1997). Gerboth (1987), for example, argues that:

...the existence of definitions matters hardly at all in deciding most issues of real-world consequence. Their contribution is to add brevity to discourse. The attempt to make them convey essential knowledge is a two-thousand-year-old source of obscurantism. Other respected disciplines are not even concerned about the precision of their definitions (p. 2).

The existing definitions of 'assets' have many shortfalls and have been criticised in the accounting literature for many years (Munter and Ratcliffe, 1980; Schuetze, 1993; Egginton, 1990; Tollington, 1998; Booth, 2003; Walker, 2003; Walker and Jones, 2003; Erhard, 2004; Johnson, 2004b; Bullen and Cook, 2005; Gore and Zimmerman, 2007; Miller and Bahnson, 2007). Despite the above argument, the IASB began to look at their definition again with a view to improvement. The following shortfalls in the existing definition of 'assets' were identified (IASB, 2006):

a) Likelihood (probable): when there is a low probability or expectation of future economic benefits then it may be argued that the asset definition is not met.

(b) Future economic benefits: an unspecified output (benefits?) without reference to the source and nature of the related inputs. Edey (1971), for example, argues that the definition should contain within itself a method for calculation that could be used and followed in practice.

(c) Past transaction or event: there is an emphasis on seeking to identify the past transaction or event that gave rise to an asset. It was argued that it would be more useful to focus on a present right or other privileged access to a present economic resource. 
(d) Control: over resources or future economic benefits should not be confused with the control exercised for the purposes of consolidation accounting. So it was proposed to replace 'control' with 'rights or other privileged access' since this avoids the problem.

The above concerns led to revisions to the definition of an asset from: 'A resource controlled by the enterprise as a result of past events and from which future economic benefits are expected to flow to the enterprise' (IASB, 2001, CF 49, pp. 53-59), to...the working definition in 2006: 'An asset is a present economic resource to which an entity has a present right or other privileged access' (IASB, 2006, p. 4), to the working definition in 2007: An asset of an entity is a present economic resource to which the entity presently has an enforceable right or other access that others do not have (IASB, 2007, p. 2).

Such changes encourage academic debate and it is often content focused (as shown below in Table 2 on semantic nuances, while leaving the overall definition-led approach intact (Whittington, 2008).

Recently, July 2013, the IASB proposed the following definition for an asset: 'an asset is a present economic resource controlled by the entity as a result of past events .....an economic resource is a right, or other source of value, that is capable of producing economic benefit'(IASB draft, 2014, section 2).

\section{Insert Table 2}

\subsection{The conceptual primacy of the asset-liability stance}

There are currently two ways one can view assets in terms of their disclosure in financial statements: the asset-liabilities view or revenue-expenses view (see Hicks, 1946; Bromwich et al., 2005; Johnson, 2004b; Bullen and Cook, 2005; Gore and Zimmerman, 2007; Miller and 
Bahnson, 2007; Kvifte, 2008).

The asset-liability view gives conceptual primacy to the balance sheet elements. Income is the net increase in the value of those elements: increases in assets and decreases in liabilities. This view of income is grounded in a theory prevalent in economics, namely, that an entity's income can be objectively determined from the change in its wealth plus what it consumed during a period (Hicks, 1946, pp. 178-179). Storey and Storey (1998), in supporting the dominance of the asset-liability view in the FASB Concepts Statement 6 (FASB, 1985) present the following logical sequence:

Figure 1: The Conceptual primacy order (Source: Storey \& Storey, 1998, p.87)

What is the asset?

What is the liability?

Did an asset or liability change, or did its value change?

Increase or decrease?

By how much?

Did the change result from:

An investment by owners?

A distribution to owners?

If not, the change must be comprehensive income.

Was the source of comprehensive income what we call:

Revenue?

Expense?

Gain?

Loss?

Proponents of the alternative revenue-expense view focus on what they view as the 
performance of the reporting entity as depicted by its reported income. The reporting of net income (or loss) for a period would be distorted unless it resulted from the proper matching of revenues and expenses in the period. Consequently, many items that are regarded as nonmonetary assets and liabilities are by-products of the matching process. Receipts of the current period that are deemed to be revenues of future periods are deferred to those periods by means of deferred credits that are treated as liabilities. Similarly, expenditures of the current period that are deemed to be expenses of future periods are deferred to those periods as deferred charges (debits) that are treated as assets. Thus, assets and liabilities are the residuals of the matching process, the debits and credits that remain on the books after they have been closed (Johnson, 2004b).

Regulatory criticism of the asset-liability view comprises:

The FASB CF (1978, para. 1.43) states that the information contained in the income statement is likely to be more useful to investors and creditors than the information in the balance sheet.

The IASB CF (2001, CF17) emphasises that information about the performance of an enterprise, in particular its profitability, is required.

The ASB CF emphasises the information required by investors for financial performance rather than the information required by investors for financial position (ASB, 1999, para. 1.13 and 1.15).

Johnson (2004b) showed that the FASB's adoption of the asset-liability view as the basis for its CF has been affirmed by others. Standard setters around the world that have developed conceptual frameworks - those in Australia, Canada, New Zealand, the United Kingdom and the IASB - have all based their CFs on the asset-liability view. Although some continue to believe that the asset-liability view emphasises the balance sheet and de-emphasises the income 
statement, this may not be the case (see ASB, 1999 for one such denial). Bullen and Cook (2005) add that the contrasting viewpoints (asset-liability versus revenue-expenses, above) were set forth and discussed at length in the December 1976 FASB Discussion Memorandum, Scope and Implications of the Conceptual Framework Project. Paragraph 66 of that document noted that critics of the revenue-expense view contend that unless vital concepts - such as income, revenues, expenses, appropriate matching and distortion of periodic net income - are clearly defined, income under the revenue and expense view is almost completely subjective. In that document and other communications, critics of the asset and liability view who favoured the revenue and expense view were challenged to define revenue, expense or income directly, without reference to assets or liabilities or recourse to highly subjective terminology like 'proper matching' (Bromwich et al., 2005). Bromwich et al. (2005) argue that there is a conceptual tension between income expressed in terms of capital value and income expressed in terms of maintainable income - see section 2.4. Further, there are also conceptual grounds for believing that the most relevant income concept for users and their economic decisions will vary with their individual circumstances and conditions. It seems likely that the new conceptual framework project of the FASB and IASB will not be able to satisfy its critics unless the project 'revisits the concepts' in a much more fundamental way. Indeed, revisiting the concepts will help the board and their constituents to understand why accounting practice has to be made up of conventions: 'To be principles-based, standards have to be a collection of (socially) useful conventions, rooted in fundamental concepts' (Bromwich et al., 2005, pp. 4-5).

\subsection{Linking the two previous subsections to capital maintenance}

The definition of an asset (see section 2.2, above) does not specify what 'future economic benefits' give rise to an increase or decrease in business value between two balance sheet dates (the dominant asset-liability in section 2.3 above). In particular, if the term 'future 
economic benefits' is taken to mean future cash inflows, then the increase or decrease in value will exclude unrealised gains, for example, from holding assets. It follows, to some extent, that if the recent notion of comprehensive income is to include such unrealised gains, then there is some degree of disconnection between the definition of an asset and this notion. By extension, this will impact on the capital maintenance concept because the 'correct' identification of income between balance sheet dates is the means by which the capital is maintained or increased. In other words, income and capital are linked and how one recognises and measures the former, affects the latter. It follows that the term 'correct' is simply political policy choice as to how one is going to view capital maintenance. Indeed, Revsine (1981) argues that an income measure is a derivative that unfolds only after deciding what capital to maintain and there has been much debate on the issue (Hicks, 1946; Gynther, 1970; Lorig, 1973; Macve, 1981; Revsine, 1981; Pratt, 1988; Bence and Frey, 2004;

Bromwich et al., 2005; Tweedie and Whittington, 1984). Thus, one can reverse the flow of the argument in this paragraph by asserting that consideration of the capital maintenance concept is a priori to the manner in which the asset-liability view is to be applied in practice.

In addition to deciding what will be recognised as being part of comprehensive income, there is then the subsequent problem of deciding how that will be measured. Tweedie and Whittington (1984, square brackets added) discuss the different styles of income equity as follows:

If income is to be measured in terms of the increases or decreases in the wealth of an enterprise, obviously some definition of that stock of wealth is required. Three basic measures of measures of wealth are evident from the literature:

(1) financial capital - the equity stake in an enterprise in money terms [...the extent to which the entity's net assets at the end of the period exceed its net assets at the beginning of the period excluding +/- distributions to owners during the accounting period];

(2) real financial capital - the equity stake in an enterprise in real terms [comments 
as per point 1 , below, adjusted for inflation...];

(3) operating capacity capital - the ability of the enterprise to maintain its ability to provide goods and services [...the extent to which the physical productive capacity of the entity at the end of the period exceeds its physical productive capacity at the start of the period excluding contributions from owners and $+/-$ distributions to owners during the period...] (pp. 281-282; cited in Jacobs, 2003, p. 3).

Revsine (1981) notes that point 1 is consistent with the historical cost income, that is, income exists only after providing for the re-establishment of the starting capital expressed in nominal historical dollars. Point 3 is consistent with the current cost income from continuing operations and the physical capital maintenance approach, that is, income exists only after providing for the re-establishment of the starting capital expressed in physical terms (Revsine, 1981, p. 386).

There is little international convergence with regards to capital maintenance concepts. The IASB CF (2001) allows an entity to choose, based on its assessment of the needs of its users, either physical capital maintenance or financial capital maintenance. The FASB, on the other hand, is more specific in adopting financial capital maintenance and rejecting physical capital maintenance. Thus, financial capital maintenance is based on historical cost accounting (Revsine, 1981) as supported by SEC (see Zeff, 2007 re political policy choices).

According to Lennard (2003), Baker and Zaman (2003) and Bence and Fry (2004), the IASB is not interested in the distribution of profit concepts. They argue, however, that if the IASB continues to ignore this issue, there will be a continuous debate about asset valuation instead. So, to repeat, any project on comprehensive income is important because it contains a hidden choice about which capital maintenance concept to adopt.

\subsection{An asset versus an expense}

The boundary between an asset definition and an expense definition is not clearly stated in the existing CFs. Samuelson (1996) notes that the main use of a definition of an asset in accounting 
practice is to classify costs incurred as either assets or expenses. He adds that a clear, unambiguous definition is needed to establish accounting policies involving the asset/expense distinction and to implement established policies in the various circumstances in which costs are incurred. In Scheutze's view (1993), the FASB's definition does not distinguish assets from expenses clearly enough and is therefore used to justify the recognition of assets which have little, if any, relevance to an assessment of the financial position of an enterprise. A clearer distinction between assets and expenses would be possible if assets were defined as property rights (Fisher, 1906; Samuelson, 1996). A theoretical foundation for defining assets as property rights can be found in Irving Fisher's The Nature of Capital and Income (1906). In his book, Fisher equated assets with property, or property rights. Property rights lie at the heart of economic activity. The modern theory of property rights focuses on how, through complex contractual arrangements, production and trade alter the rights of individuals to the use of goods and services provided by nature. One economist (Alchian, 1967) has gone so far to say that:

In essence, economics is the study of property rights over scarce resources....The allocation of scarce resources in a society is the assignment of rights to uses of resources.. ..the question of economics, or of how prices should be determined, is the question of how property rights should be defined and exchanged, and on what terms (p. 2, cited in Samuelson, 1996, p. 148).

In its discussion memorandum for the conceptual framework, the FASB (1976) considered a definition of assets based on property rights but later rejected it in favour of a definition based on probable future economic benefits. In support of this definition-led stance, Lev (2000), for example, argues that the distinction between assets and expenses is clear in that an expense is not expected to provide any benefits (where benefits are taken to mean cash flows) beyond the accounting period, while an asset does. However, on this basis, expenses like advertising and software could qualify as assets because the emphasis here is upon 'asset' measurement rather than asset recognition of the substantive nature of an asset, addressed next. 


\section{The changing nature of asset recognition}

Sterling (1984) defined recognition as 'the display of words and numerals on financial statements' (p. 3) and recognition criteria are:

...recognition tests...for the purpose of deciding which words and numerals should be displayed and which should not be displayed. Because financial statements are dated, the tests also serve the purpose of deciding when the words and numerals are displayed. Some words and numerals will satisfy the tests at one date and not satisfy them at another date thereby deciding the question of when certain words and numerals, such as revenues and expenses, will be displayed (p. 3).

Similarly, IASB CF (2001, para. 82) defines recognition as the process of depicting an item in words and by monetary amount and the inclusion of that amount in the balance sheet or income statement totals. That process is initiated by compliance with recognition criteria, the first criterion being compliance with the definition of an asset (IASB, 2001, para. 83). One may view this situation in two ways: the constituent attributes of the definition (not the definition itself) are part of a recognition criteria-led approach (a single hurdle approach) or, alternatively, compliance with the definition of an asset is a priori to further asset recognition requirements (the current two hurdle approach). To repeat, the latter approach prevails at the moment. Since compliance with the definition of an asset is the first step (IASB, 2001, para. 85-88) it is reasonable to argue that so too are its constituent attributes part of the overall recognition process. De facto, an asset is not recognised without them and, as such, it is reasonable to argue that some explanation of the fairly abstract terms like 'economic resource' or 'economic benefit' are required, if only to remove ambiguity - what is 'economic', what is 'benefit' and so on (discussed previously in section 2.2.). One can refer to this requirement in terms such as ‘recognition criteria' or simply, 'an explanation'. The point here is that it probably does not matter whether one has a two-stage 'definition and recognition' process (IASB, 2001), a onestage ‘definition with explanation’ process (under consideration by the IASB in 2009) or a onestage 'recognition criteria only' process. The point is that whatever conceptual process is 
adopted, it could be argued, it should have a practical outcome so that one can in practice accurately delineate an asset element, particularly the intangible ones, from any other element. So, for example, if rights are an essential feature of the definition and/or recognition process, then what are the rights? List them, identify their properties (contractual, statutory registration, court order, prescriptive rights, custom and practice, free goods etc.), identify dimensions where they exist (how long is a long-lived right? Are transactions merely a subset of general right of transference? etc.), possibly rank where hierarchical relationships exist between them (is a right to control a priori to a right to future use? etc.), determine what rights are essential (a right to capital and how is that to be maintained? etc.) and what rights are desirable (the right to use as security? etc.) for asset recognition to occur and so on. In other words, give the practitioner something they can actually use even if it is just a well-explained checklist. Again, recognising a potentially unrecognisable intangible asset is clearly problematic. Nevertheless, without some form of asset recognition the possibility exists that there may be little or nothing to subsequently value. Yet, as Whittington (2008) argues, the current CF confuses measurement with recognition, despite the fact that the latter is obviously a priori to the former. What seems likely to exist for asset recognition purposes in the revised CF in 2010 and until the time of writing this paper, this section is under revision as shown in Table 3.

\section{Insert Table 3}

\section{Asset measurement}

Most writers (Bullen and Cook, 2005; Bency and Fry, 2004; The Canadian Accounting Standards Board, 2006; Cooper, 2007a, 2007b; McGregor and Street, 2007; Barth, 2007; World Standard Setters Meeting, 2006(1-b), Whittington, 2008; Bradbury, 2008; Ronen, 2008; Turley, 2008; Barth, 2012) agree that the measurement process is the most underdeveloped area in the existing IASB and FASB CF's. The measurement process is defined by the IASB (2001) as: 'the determination of the monetary amounts at which the elements of financial 
statements are to be recognised and carried in the balance sheet and income statement'. Similarly, the ASB CF (1999) defines the measurement process as 'a process of deciding on the measurement basis to be used and determining the monetary amount that is appropriate under that basis'. The FASB's CF, on the other hand, separates measurement into (a) selection of the monetary unit and (b) choice of attributes. The next two subsections are framed by this attempt at decomposition.

\subsection{The selection of monetary unit}

As to the monetary unit selection, the FASB's CF adopts nominal units of money (FASB, 1984, para. 5.71, 5.72) over alternative units of a constant general purchasing power approach (see FASB, 1979, p. 12). In the IASB CF and the ASB CF, however, no preference is exercised (IASB CF, 100; ASB 6.43). The IASB and ASB just mention the use of a current unit of measure as a part of financial capital maintenance (Bence and Fry, 2004, pp. 6-7).

The measurement issue may not be as controversial today as it was when the CFs were first developed, because most major economies are currently experiencing little or no inflation (Bullen and Cook, 2005). Nevertheless, Bence and Fry (2004) argue that the IASB CF should consider accounting for price level changes in detail given that inflation is still a major problem in some of its constituent countries. It is therefore somewhat strange that there is no mention of the Current Purchasing Power (CPP) in the IASB CF, yet it forms the basis of the only reporting standard on inflation accounting (IAS 29 on Financial Reporting in Hyperinflationary Economies). CPP accounting seems to be the most likely alternative to the current 'mixed measurement' system in the case of hyperinflationary economies.

\subsection{The choice of attributes}

The IASB CF contains a list of measurement attributes: historical costs, current costs, gross or 
net realisable (settlement) value, current market value and present value of expected future cash flows. One of the main issues concerning these attributes is their labels (IASB, 2006b), because there is an interchangeable use between some of them, for example, net realisable value and exist value. Secondly, there is an oversimplification in that an apparently single measurement method can be part of a family or group method (IASB, 2006b), for example, the historical cost family includes original transaction price, original entry value, accumulated cost, allocated cost, amortised cost, combinations of accumulated, allocated and amortised costs and recoverable costs. Finally, there is the issue of how to use these attributes in the measurement process - see Table 4 .

\section{Insert Table 4}

It is evident (Bence and Fry, 2004) that the UK ASB favours 'value to the business' (VTB), or 'deprival value' for assets, whereas, to repeat, the IASB list the options but fails to recommend a preferred measurement technique. That said and unlike the ASB CF, there is no formal recognition of a 'mixed measurement' system in the IASB CF (compare with ASB 1999, appendix III, para. 55), which may suggest that it was written in an era when there was a search for 'one' system of income measurement.

One of the arguments in favour of a mixed measurement approach is that it is 'flexible in that the mix of historical cost and current value can be changed, as accounting thought develops and markets evolve'. Salvary and College (2003) conclude that the numbers in financial statements are not relevant for being based on five different attributed measurement methods (see Table 4), but, according to Cooper (2007b), mixed measurement is not necessarily a problem if there is more of a focus on 'comprehensive income' (section 2.4 previously). An implication is that the use of current value is likely to become more prevalent with the growth and development of more sophisticated markets (Bence and Fry, 2004, p. 10). Bence and Fry 
(2004), Barth (2007) and Cooper (2007b) argue that:

a) There is a drive from IASB, FASB, ASB and AcSB (Canadian Accounting Standard Board) towards fair value. Increasingly, despite the fact that many existing (and proposed) IFRS and FASB statements are based on the concept of 'fair value', it is, nevertheless, not referred to in the IASB CF (2001). Therefore, such an omission suggests that the international CF's measurement provisions are limited and alarmingly out of date.

(b) The IASB CF does not provide guidance on how to choose between these attributes, that is, they lack fully developed concepts (Bullen and Cook, 2005).

(c) The IASB CF does not distinguish between measurement techniques used for initial measurement and then subsequent measurement, although the latter event includes revaluations, impairment and depreciation, and gives rise to issues about the classification of gains or losses in statements of income and changes in equity (Bullen and Cook, 2005).

(d) A consequent issue to the initial recognition process is the subsequent recognition and derecognition criteria as the measurement attributes may differ (Bullen and Cook, 2005).

(e) The 'unit of account' is one unresolved concept that recurs in various ways in IASB's discussions about measurement issues. Specifically, whether items should be grouped at some level of aggregation or disaggregated to their lowest level of recognition. Different units of account result in different measures of impairment if the measurement attribute is historical cost. That is because if the unit is a large group of assets, the impairment of one asset may be countered by appreciation of another asset. Different units of account also result in different measures of fair value if the price for a single item is higher or lower than the per-unit price for a group of similar items. Or perhaps what appears to be a single item should be subdivided for accounting purposes. Several standard projects turn at least in part on the unit of account, and, 
according to Bullen and Cook (2005), neither CF provides useful guidance.

\section{Entity specific vs market specific recognition}

Market specific recognition means an entity looks to the market prices of assets and liabilities, which reflect market risk preferences and market expectations with respect to the amounts, timing and uncertainty of future cash flows. Entity specific recognition will differ from market value because of different expectations as to amounts or timing of future cash flows, different risk assessments or preferences (see Canadian Accounting Standards Board, 2005).

The content of this section is still located in the measurement attributes of the previous section, namely whether any measurement should be market based or not. To a large extent the question is a rhetorical one because as already indicated, the dominant conceptual stance is one based on economic decision-making, which tends to favour market-based values. However, as the subtitle implies, the issue is also a recognition issue because the referral to a market-based value for an asset is typically triggered by an entity specific event, such as a decision to purchase the asset. There is no market for many intangible assets and therefore both recognition and measurement would have to be entity specific. For instance, with internally created intangible assets, asset recognition depends on where one positions oneself. If one positions oneself in the entity specific 'camp', then, on a transaction basis, internally created intangible 'assets' have previously been expensed against income rather than being currently capitalised. Additionally, there is a wide degree of accounting discretion as to the asset or expense location of the related transaction-based debit. In theory (but almost certainly not in practice), it would be possible to trawl back through previous income statements and extract the expensed transactions that one now wishes to capitalise instead. Alternatively, if one positions oneself in the market specific 'camp', then the transactions relate to those assets, not expenses, that the market chooses to recognise and place a value upon. Linsmeier et al. (1998, p. 313), Hirschey 
and Wygandt (1985, p. 327), Guilding and Pike (1990, p. 48), Aboody and Lev (1998, pp. 162163), Barth et al. (1998, pp. 62-63) Amir and Lev (1996, p. 5) highlight the situation where expenses could be regarded as intangible assets, that is, respectively in respect of $R \& D$, advertising, marketing expenditure, software, brands and in general. All that said, there are many intangible assets, particularly those from the intellectual capital domain, that may have no transaction basis at all on which to ground asset recognition, and the related event may simply be a eureka moment disconnected from any business entity. For example, the private patent creator and subsequent major shareholder of a company producing his patented cyclonic vacuum cleaners effectively transfers control and usage of an intangible asset that is not transaction-based and, yet, it is the mainstay of the company for the life of the patent. If one had to make a choice between the two camps in this regard then, at the point where the control and future use of the intangible asset was transferred to the business, it became an entity specific event with an uncertain value. As regards the uncertain value assertion, there is no entity specific transaction-based measurement or market specific valuation-based measurement, especially with the absence of organised liquid markets for intangible assets (Maines et al., 2003). This paper stops short of addressing that thorny and longstanding accounting problem.

\section{Does the economic resource in respect of an asset comprise 'rights'?}

In the existing definition of an asset (IASB/FASB) the word 'control' dominates the definition (as shown in Table 1). In the proposed definition of an asset, the word control is replaced by 'enforceable rights or other access that others do not have': 'An asset of an entity is a present economic resource to which the entity presently has an enforceable right or other access that others do not have' (IASB, 2007, p. 2).

Fisher (1906), in his famous book The Nature of Capital and Income, equates assets with property rights, as property rights lie at the heart of economic activity. There is the mutual 
relationship between the concept of wealth and the concept of property. Wealth is used in a collective sense to include both stocks of wealth at an instant in time and flows of wealth during a period of time (Samuelson, 1996). Property is the right to use wealth. A right, according to Fisher (1906), 'is a term of jurisprudence, and brings economics into contact with the whole subject of legal and custom-sanctioned relations' (p. 20; cited in Samuelson, 1996). He defines the right of a person to the use of an article (or instrument) of wealth as 'his liberty, under the sanction of law and society, to enjoy the services of that article'. Because services owned are always future services and since all future events are uncertain, a property right can also be defined as 'the right to the chance of obtaining some or all of the future services of one or more articles of wealth' (Fisher, 1906, p. 22; cited in Samuelson, 1996).

Samuelson (1996, pp. 147-150) states that:

...a clearer distinction between assets and expenses would be possible if assets were defined as property-rights. All resources used by an enterprise have bundles of rights attached to them. These rights include the rights to use a resource, to change its form or substance, and to sell or rent it to others...Assets are equated with property and therefore represent rights to capital and income (the services of wealth). Property is the "flip-side" of wealth and is distinguishable from property value which is its quantity times its price. Assets are abstract rights that can be exchanged. Asset values are monetary representations of property rights.

One can see in his concluding comment the link between what I would regard as the central feature of any pre-measurement phase, namely, 'property rights', linked to 'asset values' as undertaken in the subsequent measurement phase of the overall asset recognition process.

Pallot (1990) explores another link involving property rights, namely the link to resources:

....assets have both a resource dimension (where a resource is that which produces benefits) and a property dimension (where property is taken to be a set of legally sanctioned rights over things and between persons with respect to things). This analysis demonstrates (and draws upon) the fact that accounting has its foundation in both economics and law (p. 81, brackets added).

The link between right and resource is also contained in the above asset definition. However, 
as Weetman (1989) rightly points out, the need to define a resource in a definition simply replaces the need to define an asset (see Samuelson, 1996). Therefore, if Weetman is correct, there is potentially an added issue of the need to define rights replacing the need to define a resource replacing the need to define an asset where the asset is intangible in nature. This is because, while one has little difficulty comprehending a tangible resource (and property), it is a somewhat problematic exercise when dealing with the notion of an intangible resource and whether this is actually a contradiction in terms? The right and resource are conflated as the means, often the legal means, of accessing future economic benefits. One can then try to be more precise about the sort of rights that might constitute the intangible resource. Honoré (1961), for example, proposes a list of 11 attributes that make up private property, including: right to control; right to use; right to manage; the right to income; the right to capital; the right to security; the right to transmissibility; the absence of a term; the prohibition to harmful use; liability to execution; and the right to a residuary character.

Booth (2003) appears to support the above argument about a conflation when he asks: 'Are assets "rights", from which an entity can expect to derive future economic benefits, or are assets the future economic benefits per se?'(p. 311).

He avoids the specific issue of what constitutes an intangible resource but, nevertheless, it is the right that would appear as an asset on the balance sheet. De facto, there must be a resource element, otherwise it would not be an asset and the only candidate in that regard is the right: '...A right is recognised as an asset if it is reported on, or incorporated in amounts reported on, the face of the financial statements of an entity'(p. 311).

Support for this 'assets are rights' argument, particularly in respect of intangible assets, is offered by Maines et al. (2003) who distinguish between physical and financial assets and intangibles as follows: 
Many intangibles like customer loyalty are not separate and saleable assets - their value can be measured only as part of the residual value of the firm. And the well-defined property rights of physical and financial assets that effectively define control and exclude others from enjoying the benefits of these assets often do not extend to intangibles (p.181).

One can conclude that the 'assets are rights' argument is of pivotal importance when dealing with intangible assets because of the absence of a recognisable 'resource' other than the 'right' itself. Likewise with respect to the economic benefits that flow from that resource because it can be argued that the exercise of that substitute right is often about preventing others from competing rather than obtaining economic benefits for oneself from the right. In other words, the economic benefit is indirect at best.

\section{The role of 'separability' in asset-based recognition}

According to IAS 38, a separable asset is the one which is: '...capable of being separated or divided from the entity and sold, transferred, licensed, rented or exchanged, either individually or together with a related contract, asset or liability’ (IASB, 2004).

The important point here is that separability is recognition based, not measurement based. The separable recognition of an asset occurs before asset measurement, otherwise one cannot be too sure of what one is measuring and transferring should be necessary. As Archer (ASB, 1995) rightly points out in this latter regard:

...the concept of separability involved is the "ontological" criterion of separate transferability, not the criterion of separate identifiability of the estimated attributable future cash flows. The latter strictly concerns the different issue of "measurability".

A related problematic issue, though, is establishing the separable recognition and transference of something that is intangible in nature. It initially appears that the only basis for intangible asset recognition to occur is actually on the basis of a measurement, typically a market-based valuation - a market specific approach that perversely gives priority to a measurement as the 
simultaneous basis for asset recognition. Thus, Napier and Power (1992) comment with respect to such measurements that:

Measurement separability goes further by effectively collapsing all three stages of identification, recognition and measurement into one. In other words, if we can measure the resource in an acceptable manner, then it is difficult to resist the identification of the resource as an asset and its consequent recognition in financial statements...such methods are claimed to be acceptable because separate identification is possible, but we argue that such methods determine, rather than depend upon, separability. Because of this apparent circularity, the acceptability of such methods cannot be determined simply by appeals to the idea of separability, because this idea is not independent of measurement (pp. 88-90).

However, this 'measurement separability' or 'measurement only' view is perhaps unbalanced: asset measurement should not 'determine' the separable recognition of assets because, to repeat, the latter logically is apart from the former (see Whittington, 2008). Consequently, there is no 'apparent circularity' because, as Archer implies above, separability has a 'transferability', as well as a 'measurability' aspect to it. It can be argued that a physical, separable recognition can occur anyway on the basis of a documentary representation of the intangible asset, such as patent letters or trademark registration documents. Additionally, one may argue that Archer's 'transferability' is one of many functions of a separable asset that should form part of the recognition process for intangible and tangible assets alike.

El-Tawy and Tollington (2008a, p. 727) define separability as:

All the individual assets of a business, whether intangible or not, are separable from each other when it is possible to aggregate or disaggregate them without loss or gain in the recognition and measurement of those individual assets such that the sum of them would always be equal to the whole of the assets of the business.

A problem though is what constitutes 'the whole of the assets' where, for example, wealth creating human 'assets' are deliberately kept off the balance sheet. Another problem is the determination of 'individual assets' (is it bricks and mortar or a building?), particularly where some assets are often bundled together into a single unit, as with financial instruments. Thus, 
as Egginton (1990) rightly points out, the ability to identify a resource as a bundle of legal rights does not exhaust the notion of separability.

Some notable academics think that separability should be part of the definition, for example Baxter (cited in ASB, 1995, p. 62). Similarly, Chambers (1966, p. 103) argues that 'an asset is defined as any severable means in the possession of an entity'. Separability does appear in a German definition of an asset. More importantly, it is a 'balanced' definition insofar as it has both of Archer's transferability and measurability aspects of separability in it. Thus, Schmalenbach-Gesellschaft für Betriebswirtschaft e.V. (SG) (2005) define an asset (Vermögensgegenstand) as follows:

It must represent (1) an economic value, (2) that value can be separated from the entity (i.e. transferred or sold independently of other assets) and (3) it can be valued individually. Intangibles that were acquired (separately or as part of a business combination) and self-generated (internally generated) intangibles considered to be sold (current items) must be recognised as an asset if they comply with the above definition (pp. 70-71).

Upton (2001, pp. 70-71) on the other hand, in offering a list of potential intangible assets', states that 'separability and contractual/legal rights are not essential characteristics of an asset, but they are evidence of one characteristic that is essential - control'. That said, neither separability nor control appear in the latest definition of an asset, as previously presented in section 2.2.

Separability has a recognition dimension and a measurement dimension but note that recognition is a priori to measurement, for the reason given previously. That priority is reversed with Napier and Power's (1992) notion of measurement separability and this reversal should not be surprising, given the overall economic orientation to accounting and the existing definition of an asset (IASB, 2001) that emphasises the measurable 'future economic benefits' as a basis for asset recognition. However, one example of the perversity of the 'measurement 
substituting for recognition' approach is evident in purchased goodwill. From a recognition viewpoint, purchased goodwill is inseparable from the other assets of a business assuming it is an asset at all (prior to 1997 in the UK it was expensed instead). From a measurement viewpoint, however, it is made separable according to an accounting rule that simplistically says: take the amount paid to acquire a business away from the fair value of the separable assets so acquired and the arithmetic difference (the measurement) is recognised as an asset. The separable measurement replaces any consideration of the 'rights' present in goodwill, assuming it has any?

To summarise the above themes, the following table shows the main ones that have to be taken into consideration when the standard setters define the notion of asset.

Insert Table 5

\section{A suggested avenue for asset-based recognition criteria in the pre-measurement phase}

Scholars (El-Tawy \& Tollington, 2008, 2013) have suggested some new avenues for the assetbased recognition criteria in the pre-measurement phase. The asset-based recognition criteria presented in this paper break free from the narrow definitional and rule based perspective of accounting epistemology to offer an alternative view based on the recognition of on wider transaction basis. From a social construction point of view, one can notice the epistemological basis for asset recognition, this asset recognition constitutes a social construction that purports to represent economic reality. The epistemological basis of asset within the financial accounting domain is dominated by rules. Those rules are supposedly grounded on overarching conceptual frameworks (ASB, 1999; FASB, 1984, 1985; IASB, 2001) and the results of institutionally led external consultation processes legitimate the conceptual frameworks and rules, and the accounting regulatory bodies creating them, in the 'eyes' of society. According 
to those socio-political policy choices, there will be many 'assets' that are not disclosed on the balance sheet. There are also some issues related to this, where there is no line to distinguish an asset from an expense. Although asset definition occupies a central role in the asset recognition process, but it fails to distinguish an asset from an expense. Combined with the definition of a liability, the asset- liability view is the conceptual primacy for all other elements definition.

Combined with this epistemological basis for asset recognition. We, as accountants, are in need to broaden our view about the basis of recognition, especially in nowadays environment where the non-physical assets play vital roles in the surviving and growth of businesses. The notion of 'artefact' is widely used as logo or picture in the marketing domain. But when it is used in the accounting domain, it means any documentary and/ or documentary basis. When an economic resource needs to be recognized based on this documentary and/ or physical basis, there should be any evidence to support this, not only based our recognition basis on a transaction but to broad the area of this recognition.

The notion of 'separable in nature' is the core recognition criteria to separate the candidate asset from another. The asset is an 'economic resource' which is a candidate to be recognised in the financial statement. Combining the rights with separability, the 'rights' becomes an important issue where the entity actual transference is a necessary condition for the recognition of a financial instrument (a sale), and there may be a series of actual transactions-based transferences in that regard, only the end-user of the instrument possesses the capability to transfer 'use' onwards. This issue though is not peculiar to financial instruments since, for example, there can be an actual transfer of stocks held for use by a transferee where the control and the related risks of control still remain with the transferor - the capability is restricted and can be curtailed. The core central right is the right to control an economic resource. The 
economic resource is the investment of the entity to produce benefits out of this economic resource. This economic resource may be scarce in nature and the entity should have the right to control it. In this case the notion of 'economic' should be expressed in terms of ££££ only, it should express the monetary and non monetary terms of the notion of benefits. Therefore, the candidate asset should be 'capable of being measured' to further pass to the measurement phase. In summary to the above, asset based recognition criteria can be with the notions of separability, rights-based economic resource and capability of being measured with an artefact basis

This suggested avenue for asset based recognition criteria is vital to intangible and home grown assets to start showing in the financial statements.

\section{Conclusion}

Over the decades there has been a broadening of the role of assets from their legalistic, property-centred role in the settlement of debts to one that embraces an economic decisionmaking role. Accompanying this shift in emphasis was the standard-setters' decision to 'define' their intended construction of financial reality in economic terms. However, determining economic wealth in terms of increases and decreases in capital and related income is problematic, because it depends on other political policy decisions. Notable in that regard was/is the primacy given to the definition of asset and, by extension, to the balance sheet as a representation of changes in the value of assets over time. However, reflecting changes in value is dependent on further political policy decisions concerning the maintenance of capital and the nature of the income, comprehensive or otherwise, that is to be recorded. Finally, on the debit side of the balance sheet, the 'defined' construction includes an asset definition that is not particularly good at distinguishing an asset from an expense with the impact that this obviously 
has on the recording of income and capital.

Somewhat speculatively (if only because the revised IASB CF is still under review at the time of writing), what can be seen in such developments is a move towards a position where one asks: does the item comply with the definition of an asset? And, if so, then measure it. In determining compliance with the definition of an asset, it is supported by an explanation or 'qualitative characteristics', but there is no emphasis upon legalistic, transaction-based recognition or indeed, the reliability of transaction-based measurement. Rather, what can be seen is a firm affirmation of the economic decision-useful stance and a laying down of an asset recognition basis, unrestricted by the limitations of transaction-based cost records, that paves the way towards the use of fair values at the initial recognition stage.

With regards to the issue of 'measurement', it cannot be completely divorced from the subject of this research, namely, the 'pre-measurement' phase in the accounting recognition of assets. My engagement with the issue of measurement here is to highlight some of the crossover points between pre-measurement and measurement. For example, the unit of account question involves both the recognition of what will constitute a unit, as well as how to measure it. In general terms though, it is the Bullen and Cook (2005) assertion as to underdeveloped concepts that is pertinent here and to work the contribution of this research is directed.

The 'assets are rights' argument is of pivotal importance when dealing with the definition of and the asset recognition criteria in respect of the intangible assets as for their nature. The same as the right to this economic resource (candidate asset), there should be a control over this resource to prevent others from obtaining the benefits from this resource. This in turn raises questions about the causal linkage between the recognition and disclosure of a 'right' on the balance sheet when the measurement of the economic benefit from that right is so uncertain. However, that is a measurement issue that does not prevent the recognition of the right as an 
asset even if the recoded value is a nominal figure.

The notion of 'separability' is a mile stone in the asset recognition process, although the existing conceptual framework for financial reporting does not contain this notion. It is only applicable with the identification of intangibles - IAS 38 (IASB, 2004). However, when it comes to reality, it has a significant power in the process of asset recognition. Separability is a concept that should be applied in the process of asset recognition.

After this synthesis review of the literature, it is clear that there are weakness and criticisms towards the existing asset definition and asset recognition criteria in the existing CFs. In exploring the case for asset recognition criteria I must unavoidably span most of the themes in this area of research into some research future avenues which can be as follows: first, this research is a starting point, some empirical research may be necessary to elaborate and verify these recognition criteria in practise. As empirical research would show the settings and applicability of those themes and would enrich the use of the pre-measurement asset based recognition criteria. Second, the applicability of those pre-measurement recognition criteria to different types of un-recognisable assets, in other words, to apply those asset-based recognition criteria to different types of assets who are currently not recognised in the financial statements. And finally, the asset measurement bases and the capability of an asset to be measured and the use of different measurement is another venue for research under this ungoing debate.

\section{References}

Aboody D, Lev B (1998), “The Value Relevance of Intangibles: The Case of Software Capitalization”. Journal of Accounting Research, Institute of Professional Accounting, Vol.36 Supplement, pp161-191.

Archer, S. (1993): 'On the methodology of a conceptual framework for financial accounting. Part II: From jurisprudence to soft systems analyses, Accounting, Business and financial History, 3(1), pp. 81-108.

Arden D (2005), “An accounting history of capital maintenance: Legal precedents for managerial autonomy in the United Kingdom”. Accounting Historians Journal, pp1-25 
Barth, M. (2007), “Standard-setting measurement issues and the relevance of research”. Accounting and Business Research, Special Issue: International Accounting Policy Forum, pp7-15

Barth, M. (2012), "Measurement in financial reporting: The need for concepts”. AMIS Conference.

Bence, D. and Fry, N. (2004), “The International Accounting Standards Baord’s Search for a General Purpose Accounting Model”. Journal of Financial Reporting, Regulation and Governance, vol. 3 , no.1, pp 1-29.

Bertoni M, De Rosa B (2005), Comprehensive income, fair value, and conservatism: A conceptual framework for reporting financial performance, A paper for the $5^{\text {th }}$ International Conference on European Integrations, Competition and Cooperation (Lovran, April 22-23)

Booth B (2003), "The Conceptual Framework as a Coherent System for the Development of Accounting Standards". ABACUS, Vol. 39, iss 3, pp. 310-324.

Bradbury, M.(2008), “Discussion of Whittington”. ABACUS, Vol.44, No.2, pp.169180.

Bromwich M, Macve R, Sunder S (2005), FASB/IASB Revisiting the Concepts: a comment on Hicks and the concept of 'income' in the conceptual framework, A comment letter sent to International Accounting Standards Board as part of their "new conceptual framework project”, 24 July, pp1-6

Brouwer, A., Hoogendoorn, M. \& Naarding, E. (2015) "Will the changes proposed to the conceptual framework's definitions and recognition criteria provide a better basis for IASB standard setting?”, Accounting and Business Research, 45:5, 547571, DOI: $10.1080 / 00014788.2015 .1048769$

Bullen H, Crook K (2005), "Revisiting the Concepts: A New Conceptual Frame work Project”. Available on line: www.iasb.org/project/communications-papers.pdf

Canadian Accounting Standards Board (2007). A discussion paper prepared for the International Accounting Standards Board (IASB) on Measurement Bases For Financial Accounting - Measurement On Initial Recognition, obtained from IASB website www.iasb.org

Cauwenberge PV, De Beelde I (2007), “On the IASB Comprehensive Income Project: An Analysis of the Case for Dual Income Display”. ABACUS, Vol.43, No.1, pp126

Chambers, R. (1966). Accounting, Evaluation and Economic Behavior. Englewood Cliffs, N. J.: Prentice Hall.

Cooper, S. (2007), "Discussion of Standard-Setting Measurement Issues and the Relevance of Research”. Accounting Business Research: Special Issue: International Accounting Policy Forum, pp.17-18.

Cooper, S. (2007,a). Performance measurement for equity analysis and valuation. Working paper. Available on line: www.ubs.com/investmentresearch

Dean, G.W. and Clarke, F.L. (2003), " An Evolving Conceptual Framework? ". ABACUS, vol.39, iss. 3 pp. 279-297.

Edey, H.A. (1971), “The True and Fair View”. Accountancy (August,1971)pp.

Edwards E. and Bell P. (1961) "The Theory and Measurement of Business Income, University of California University Press

Egginton, D. (1990), “Towards Some Principles For Intangible Asset Accounting”. Accounting and Business Research, Vol. 20, No. 79, pp. 193-205.

El-Tawy N, Tollington T(2008), “The recognition and measurement of brand assets: an exploration of the accounting/marketing interface”. Journal of Marketing Management, Vol.24, No.7/8, pp711-732 
El-Tawy, N. and Tollington, T. (2008-b). "Differentiating brand assets from goodwill assets: The artefact based approach to the accounting recognition of marketing related assets”. British Accounting Association; 2008; held at Blackpool; Canadian Academic Accounting Association- 2008, May 29-30. Winnipeg, Canada

Erhard, L.(2004), “Chapter 3: The IASC’s Conceptual Framework - an Obstacle to International Harmonisation?”. Ludwig Erhard Lectures. Available on line: info.worldbank.org/etools/docs/voddocs/458/1640/Ch3_IASC\%20conceptual\%2 0framework.pdf

Financial Accounting Standards Board (1978), Statement of Financial Accounting Concepts No. 1, Objectives of Financial Reporting of Business Enterprises, (Norwalk, CT). .

Financial Accounting Standards Board (1980), Statement of Financial Concepts No. 2, Qualitative Characteristics of Accounting Information, (Norwalk, CT).

Financial Accounting Standards Board (1984), Statement of Financial Accounting Concepts No. 5, Recognition and Measurement in Financial Statements of Business Enterprises, (Norwalk, CT).

Financial Accounting Standards Board (1985), Statement of Financial Accounting Concepts No. 6, Elements of Financial Statements, (Norwalk, CT). .

Financial Accounting Standards Board (2000), Statement of Financial Accounting Concepts No. 7, Measurement, (Norwalk, CT). .

Fisher I (1906), The Nature of Capital and Income, Reprints of Economic Classics, Augustus M Kelly Publisher, New York, reprinted 1965.

Gerboth DL (1987), “The Conceptual Framework: Not Definitions, But Professional Values”. Accounting Horizons, American Accounting Association, Vol. 1, No.3, pp1-8

Gore R, Zimmerman D (2007), "Building the Foundations Reporting: The Conceptual Framework”. The CPA Journal 77:8, pp. 30-34.

Gore, P. 1992. The FASB Conceptual Framework Project 1973-1985: An Analysis. Manchester, U.K.: Manchester University Press

Guilding C, Pike R (1990), Intangible Marketing Assets: A Managerial Accounting” Perspective, Accounting and Business Research, Vol.21, No.18, pp41-49

Hicks J. (1946), 'Income' + Chapter XIV of Value and Capital $\left(2^{\text {nd }}\right.$ edition: Clarendon Press, 1946) reprinted in Parker RH, Harcourt GC, and Whittington G, Readings in the Concept and Measurement of Income ( $2^{\text {nd }}$ edition: Philip Allan, 1986)

Hines R. (1988), "Financial Accounting: In Communicating Reality, We Construct Reality”. Accounting, Organizations and Society, Vol.13, No.3, pp251-261.

Hirschey M. and Weygandt M. (1985), "Amortization Policy for Advertising and Research and Development Expenditures". Journal of Accounting Research, Institute of Professional Accounting, Vol.23, No.1, pp326-335

Honoré A. (1961) Ownership. In Guest AG (ed) Oxford Essays in Jurisprudence, Oxford University Press, Ch.5.

IASB (2001), Framework for the Preparation and Presentation of Financial Statements, International Financial Reporting Standards, International Accounting Standards Board, April.

IASB (2003), Reporting Comprehensive Income, International Accounting Committee Foundation.

IASB (2003), Reporting Comprehensive Income, International Accounting Committee Foundation. 
IASB (2005), Information for Observers on Conceptual Framework (Agenda Paper 3), available on line: www.iasb.org

IASB (2005), World Standard Setters Meeting: Agenda Paper, Conceptual Frame work: Asset definition Project, International Accounting Standards Board, September, pp1-12.

IASB (2006), Information for Observers: WORLD STANDARD SETTERS MEETING, SEPTEMBER 2006, LONDON, AGENDA PAPER 1A, www.iasb.org

IASB (2006a), Preliminary Views on an Improved Conceptual Framework for Financial Reporting: The Objective of Financial Reporting and the Qualitative Characteristics of Decision-Useful Financial Reporting Information, International Accounting Standards Board

IASB (2006b), “Conceptual Framework Project: Measurement Phase Plan”. International Accounting Standards Board, London, UK.

IASB (2006-c), “First Steps Towards a Convergent Conceptual Framework”. International Accounting Standards Board, pp.9-11.

IASB (2006-d), World Standard Setters Meeting: Agenda Paper 1B, Conceptual Frame work Project, International Accounting Standards Board, September, pp1-6.

IASB (2006-e), Identifying the Unit of Account for the Fair Value Measurement of Reserves and Resources (Agenda Paper 4B), International Accounting Standard Board, www.iasb.org.

IASB (2007), Information for Observers on Phase B Elements: Definition of an Asset (Agenda Paper 3), International Accounting Standards Board, www.iasb.org

IASB (2008), Exposure Draft of: An improved Conceptual Framework for Financial Reporting: Chapter 1: The Objective of Financial Reporting Chapter 2:

Qualitative Characteristics and Constraints of Decision-useful Financial Reporting Information. Available on line: www.iasb.org

Johnson, T. (2004), “Understanding the Conceptual framework” FASB Report.

Lev B, Zarowin P (1999), "The Boundaries of Financial Reporting and How to Extend Them”. Journal of Accounting Research, Institute of Professional Accounting,Vol.37, No.2, pp353-385

Linsmeier TJ, Boatsman JR, Herz RH, Jennings RG, Jonas GJ, Lang MH, Petrone KR, Shores D, Wahlen JM (1998) "Response to IASC Exposure Draft E60 “Intangible Assets”, Accounting Horizons, American Accounting Association, Vol.12, No.3, pp312-316

Littleton AC (1953), Structure of Accounting Theory, (Illinois: American Accounting Association)

Maines L, Bartov E, Fairfield P, Hirst D (2003), “Implications of accounting research for the FASB's initiatives on disclosure of information about the intangible assets”. Accounting Horizons; Jun 2003; 17, 2; pp. 175-185

McGregor, W. and Street, D. (2007). "IASB and FASB Face Challenges in Pursuit of Joint Conceptual Framework". Journal of International Financial Management and Accounting 18:1.pp. 39-51.

Miller, P. and Bahnson, P. (2007), “The Top 10 Reasons to Fix the FASB's Conceptual Framework”. Strategic Finance, 89; 1pp.42-49.

Mozes, H. (1992), “The FASB's Conceptual Framework and Political Support: The Lesson From Employee Stock Options”. ABACUS, September

Munter, P. and Ratcliffe, T. (1980), “On the Attribute of an Asset”. ABACUS, Vol.16, No.2, pp.116-123.

Napier C, Power M (1992), "Professional Research, Lobbying and Intangibles: A Review Essay”. Accounting and Business Research, Vol.23, No.89, pp85-95 
Nobes, C. \& Stadler, C. (2015) The qualitative characteristics of financial information, and managers' accounting decisions: evidence from IFRS policy changes, Accounting and Business Research, 45:5, 572-601, DOI: 10.1080/00014788.2015.1044495

Newberry S (2003), "Reporting Performance: Comprehensive Income and its Proponents”. ABACUS, Vol.39, No.3

Page M (2005), "The search for a conceptual framework - Quest for a holy grail or hunting a snark". Accounting Auditing and Accountability Journal, Vol.18, No.4, pp565-576

Pallot J (1990), “The Nature of Public Assets: A Response to Mautz”. Accounting Horizons; Jun 1990; 4, 2; pp. 79-85.

Popper, K. (1962), The Open Society and its Enemies, Vol.2, London: Routledge \& Kegan Paul, p19.

Pyke, C. (1999), “The accounting conceptual framework”. ACCA Bulletin, June 1999

Revsine L (1973), Replacement Cost Accounting, Prentice-Hall

Ronen, J. (2008), “To Fair value or Not to Fair Value: A Broader Perspective”. ABACUS, Vol.44, No.2, pp181-208.

Salvary, S. and College, C. (2003), "Financial Accounting Information and The relevance/Irrelevant Issue”. Global Business \& Economics Review Volume 5 No.2 pp:140-175.

Samuelson, R. (1996), “The Concept of Assets in Accounting Theory”. Accounting Horizons, American Accounting Association, Vol.10, No.3, pp147-157

Schuetze, W. (2001), "What Are Assets and Liabilities? Where is True North? (Accounting That My Sister Would Understand)'”. ABACUS,Vol. 37, No. 1, 2001 pp. 1 - 25

Shapiro B (1997), "Objectivity, relativism and truth in external financial reporting: What's really at stake in the disputes?”. Accounting, Organizations and Society, Vol.21, No.2/3, pp289-315

Storey, R. and Storey, S. (1998). The Frame work of Financial Accounting Concepts and Standards.

Sundgaard, E. (1997), “Accounting for R\&D Expenditure - from an EC-harmonisation Perspective with a Special Focus on the Preparers' View - a Comparative Study in three EC-countries”. Southern Denmark Business School, Research Report No. 47.

Sundgaard, E. (2000), "A European Conceptual Framework for Accounting: Does it exist?". Sixth Interdisciplinary Perspectives On Accounting Conference, 10th 12th July 2000, Manchester, England

Tollington, T. (1998), "What are Assets Anyway? Some Practical realities”. Management Decision, 36/7,pp.448-455.

Tollington, T. (2006), "UK Goodwill and Intangible Asset Structuration: The FRS10 rule creation cycle”. Critical Perspectives on Accounting, Vol.17, No.1, pp799826

Turley, S. (2008), “Discussion of Ronen”. ABACUS, Vol.44, No.2, pp.209-216.

Walker R (2003), "Objectives of Financial Reporting". ABACUS, Vol.39, iss3, pp. 340355

Walker R, Jones S (2003), “Measurement: A Way Forward”. ABACUS, Vol.39, iss3, pp. 356-376

Weetman P (1989), Assets and Liabilities: Their definition and Recognition, ACCA Research Report No. 14, Certified Accountant Publications Ltd, London 
Whittington, G. (2008), "Fair value and the IASB/FASB conceptual framework project: An alternative view”. ABACUS, Vol.44, No.2, pp139-168

Williams, S. (2003), “Assets in Accounting: Reality Lost”. The Accounting Historians Journal, December.

TABLE 1: DEFINITION OF AN ASSET

\begin{tabular}{|c|c|c|c|}
\hline Components of CF & IASB (2001) & FASB (1978-1985) & Comments \\
\hline 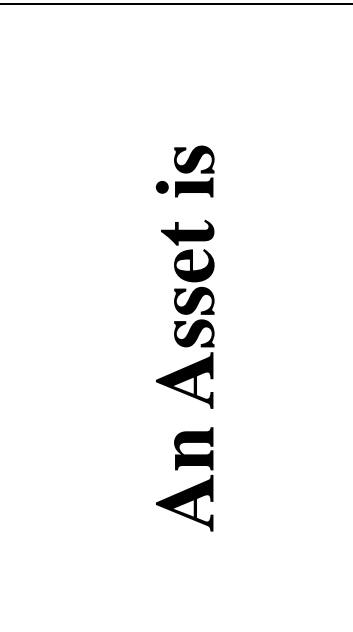 & $\begin{array}{l}\text { A resource controlled by } \\
\text { the enterprise as a result } \\
\text { of past events and from } \\
\text { which future economic } \\
\text { benefits are expected to } \\
\text { flow to the enterprise } \\
\text { (CF 49, 53-59). }\end{array}$ & $\begin{array}{l}\text { Probable future } \\
\text { economic benefits } \\
\text { obtained or controlled } \\
\text { by a particular entity as } \\
\text { a result of past } \\
\text { transactions or events } \\
(6.25-33) \text {. }\end{array}$ & $\begin{array}{l}\text { Definition based. } \\
\text { Similar re “control”, } \\
\text { “future economic } \\
\text { benefits”, “past } \\
\text { transactions” and / or } \\
\text { “events” and the } \\
\text { 'probability’ for } \\
\text { future economic } \\
\text { benefits. }\end{array}$ \\
\hline
\end{tabular}

TABLE 2: WHAT EXITS VS. WHAT IS PROPOSED IN ‘ASSET’ DEFINITION 


\begin{tabular}{|l|l|}
\hline What the Board retained from the old & Resource \\
definition in the new definition? & \\
\hline $\begin{array}{l}\text { What the Board omitted from the old } \\
\text { definition in constructing the new } \\
\text { definition in 2007? }\end{array}$ & Expected \\
& Fast events (past time frame) \\
\hline $\begin{array}{l}\text { What the Board retained from the old } \\
\text { definition in constructing the new }\end{array}$ & Resource \\
\hline $\begin{array}{l}\text { What the Board added to the new } \\
\text { definition? }\end{array}$ & Present (time frame) \\
\hline
\end{tabular}

\section{TABLE 3: RECOGNITION CRITERIA: EXISTING VS. PROPOSED}

\begin{tabular}{|l|l|l|}
\hline $\begin{array}{l}\text { What the IASB retained from the } \\
\text { old asset recognition criteria. }\end{array}$ & Compliance with the definition of an asset \\
\hline $\begin{array}{l}\text { What the IASB may omit* from the } \\
\text { old asset recognition 'criteria' in the } \\
\text { new asset recognition (or rather, } \\
\text { definition - led) 'process'. }\end{array}$ & Probable...future economic benefit & Measured with reliability. \\
\hline $\begin{array}{l}\text { What the IASB added to the CF in } \\
\text { respect of the new asset recognition } \\
\text { 'process'. }\end{array}$ & $\begin{array}{l}\text { "Measured reliably" changed to "faithful } \\
\text { representation”. }\end{array}$ \\
\hline $\begin{array}{l}\text { What, subjectively, may be said to } \\
\text { be missing in respect of the new } \\
\text { asset recognition 'process'. }\end{array}$ & $\begin{array}{l}\text { Measurability (recognition of the parameters for } \\
\text { measurement, not the measurement methods } \\
\text { themselves). }\end{array}$ \\
\hline
\end{tabular}

* Since the process is not yet complete, this situation may change. 
Table 4: MEASUREMENT ATTRIBUTES MENTIONED IN THE IASB CONCEPTUAL FRAMEWORK (Bence and Fry, 2004)

\begin{tabular}{|l|l|}
\hline The measurement attribute & IASB Framework \\
\hline Fair value & $\begin{array}{l}\text { Not mentioned in Framework, but defined in } \\
\text { the IAS 39 and SFAS 157 }\end{array}$ \\
\hline Historical Cost & Defined (CF 100a) \\
\hline Replacement Cost & $\begin{array}{l}\text { Defined and referred as 'current cost' (CF } \\
100 \mathrm{~b})\end{array}$ \\
\hline Net Realizable Value & Defined (100c) \\
\hline Present Value & Defined (100d) \\
\hline Value to the Business or Deprival Value & Not mentioned \\
\hline
\end{tabular}

Table 5: ASSET NOTION BASED THEMES

\begin{tabular}{|c|c|}
\hline Themes & Literature Review \\
\hline Asset definition & $\begin{array}{l}\text { The literature is often content focused } \\
\text { on semantic nuances, whilst leaving the } \\
\text { overall definition - led approach intact. } \\
\text { The definition of an asset appears to } \\
\text { occupy a central role in the accounting } \\
\text { recognition and measurement of assets } \\
\text { (see Schuetze, 1993; Egginton, 1990; } \\
\text { Booth, 2003; Walker, 2003; Walker } \\
\text { and Jones, 2003; Erhard, 2004; } \\
\text { Johnson, 2004; Bullen and Cook, 2005; } \\
\text { Gore and Zimmerman, 2007; Miller } \\
\text { and Bahnson, 2007). }\end{array}$ \\
\hline
\end{tabular}




\begin{tabular}{|c|c|}
\hline Asset recognition vs. measurement & $\begin{array}{l}\text { Common features of existing asset } \\
\text { recognition criteria refer to the linkage } \\
\text { to the definition of an asset, in } \\
\text { particular, the ability to generate future } \\
\text { economic benefits and that those } \\
\text { benefits should be measured reliably. } \\
\text { There is an overlap between asset } \\
\text { recognition criteria and asset } \\
\text { measurement (Whittington, 2008). }\end{array}$ \\
\hline Rights & $\begin{array}{l}\text { Are asset 'rights'? (Booth, 2003; } \\
\text { Fisher, 1906; Weetman, 1989; } \\
\text { Samuelson, 1996, IASB, 2006 \& 2007). }\end{array}$ \\
\hline Market vs. entity events & $\begin{array}{l}\text { As regards the uncertain value } \\
\text { assertion, there is no entity - specific } \\
\text { transactions-based measurement or } \\
\text { market-specific valuations - based } \\
\text { measurement (Maines et.al; 2003, } \\
\text { AcSB, 2006). }\end{array}$ \\
\hline Economic resource & $\begin{array}{l}\text { Assets have both a resource dimension } \\
\text { (where a resource is that which } \\
\text { produces benefits) and a property } \\
\text { dimension (where property is taken to } \\
\text { be a set of legally sanctioned rights over } \\
\text { things and between persons with } \\
\text { respect to things) (Pallot, 1990; } \\
\text { Honore, 1961). }\end{array}$ \\
\hline Separability & $\begin{array}{l}\text { As regards the notion of 'separability', } \\
\text { it has a role in the asset - based } \\
\text { recognition process (ASB, 1995; } \\
\text { Napier \& Power, 1992; Egginton, 1992; } \\
\text { Upton, 2001). }\end{array}$ \\
\hline Transaction - based dominance & $\begin{array}{l}\text { The dominance of the transaction based } \\
\text { leads to exclude many assets from the } \\
\text { financial statements (Tollington, 2001). }\end{array}$ \\
\hline An asset vs. an expense & $\begin{array}{l}\text { The boundary between an asset } \\
\text { definition and an expense definition is } \\
\text { not clearly delineated an asset from an } \\
\text { expense (Scheutze, 1993). }\end{array}$ \\
\hline Asset measurement & $\begin{array}{l}\text { It is not the assets per se that are } \\
\text { measurable, rather, it is their function } \\
\text { that is measurable. The function } \\
\text { envisaged here is the capacity to } \\
\text { increase or decrease business value } \\
\text { through holding assets (capital gains or } \\
\text { losses) or using assets (revenue gains or } \\
\text { losses) to increase or decrease income }\end{array}$ \\
\hline
\end{tabular}




\begin{tabular}{|c|c|}
\hline & $\begin{array}{l}\text { (whether realised or not), the increases } \\
\text { or decreases being known together as } \\
\text { comprehensive income (Bertoni and De } \\
\text { Rosa, 2005; Cauwenberge and } \\
\text { De Beelde, 2007; IASB, 2003; } \\
\text { Newberry, 2003; Barker, 2004). }\end{array}$ \\
\hline Going concern & $\begin{array}{l}\text { Going concern as an accounting } \\
\text { assumption that underpins accounting } \\
\text { generally and asset recognition in } \\
\text { particular (Tweedie and Whittington, } \\
\text { 1990). }\end{array}$ \\
\hline $\begin{array}{l}\text { Qualitative Charactertics of } \\
\text { Financial Information }\end{array}$ & $\begin{array}{l}\text { Scholars (Whittington, 2008, Nobes \& } \\
\text { Stadler, 2015) have showed how } \\
\text { qualitative charactertics have been } \\
\text { affected by the valuation of assets. The } \\
\text { qualitative charactertics for financial } \\
\text { information, as, financial information } \\
\text { should be relevant and reliable, } \\
\text { Relevance: 'The Group believes that } \\
\text { subsequent measurement using the fair } \\
\text { value model provides more relevant } \\
\text { information about the financial } \\
\text { performance of these assets'. Faithful } \\
\text { representation: 'Management believes } \\
\text { that the change will more fairly present } \\
\text { the fair value of assets and liabilities } \\
\text { related to retiree benefits in the } \\
\text { company's balance sheet and will } \\
\text { eliminate significant volatility in its } \\
\text { results of operations resulting from } \\
\text { certain plans, the participants of which } \\
\text { are all, or almost all, fully eligible to } \\
\text { receive benefits' (Nobes \& Stadler, } \\
\text { 2015, p. } 599 \text { ) from the above scholar, it } \\
\text { shows how much importance } \\
\text { accounting for assets in general and }\end{array}$ \\
\hline
\end{tabular}




\begin{tabular}{|l|l|}
\hline intangibles in specific is vital and it \\
should be consistent and comparable \\
whether on the same level of other \\
firms in the same industry or different \\
points of time for the same company. \\
So this is the duty of policy makers and \\
standard setters to produce an IAS for \\
the recognition, measurement \& \\
disclosure of the home grown \\
intangibles, so to settle the battle \\
through an issuance of a model to help \\
accountants to measure such a new \\
asset, so this will help the users to \\
depend more on the financial \\
statements.
\end{tabular}

